\title{
BLOOD PERFUSION OF THE KIDNEY OF LOPHIUS PISCATORIUS L.
}

\author{
By L. Brull, E. Nizet and E. B. Verney, F.R.S., \\ with the collaboration of $\mathrm{L}$. Wilsens \\ From the Plymouth Laboratory and Institut de Clinique et Policlinique Médicales, \\ Liège, Belgium
}

\section{(Text-fig. I)}

It is well known that the kidney of the adult Lophius piscatorius (L.) is practically aglomerular, some of the original glomeruli disappearing late in the young animal, as we have been able to confirm by the examination of fishes a few centimetres long. The kidney of Lophius receives only small amounts of arterial blood, its main supply being by venous blood from the caudal vein. Several attempts have been made by previous authors to investigate the secretion of Lophius kidney, and to these reference has been made in a paper in which the chemical composition of the blood and urine are dealt with (Brull \& Nizet, I953). We are not aware of publications on blood perfusion experiments on Lophius kidneys.

The aim of the present research was to study the secretion of the perfused Lophius kidney and its response to variations of venous pressure at the entrance to the organ, and to measure the blood and urine flows with a view to determining whether an aglomerular kidney is sensitive, and to what extent, to variations in its circulation. In a series of previous publications one of us, with his collaborators (Brull \& Dor, I940; Brull \& Louis-Bar, I950, I953), has investigated the response of the glomerular kidney of the dog to wide variations of blood pressure. The main result of these experiments was that the blood flow through the dog's kidney in the whole animal is to a large extent independent of variations of blood pressure from $100 \mathrm{~mm}$. up to $330 \mathrm{~mm}$. $\mathrm{Hg}$, while the urine flow responds regularly to these variations. Previous research on isolated perfused kidneys of the dog had regularly shown increases of blood flow in response to increases in perfusion pressure.

\section{METHods}

Several favourable conditions had to be realized in order to permit the organization of our experiments: a large supply of good-sized Lophius, brought in well alive (so allowing the gathering of sufficient amounts of heparinized blood for perfusion) and with kidneys of sufficient size to permit catheterization of the caudal vein and ureters, etc. These conditions were fulfilled 
beyond our expectations at the Plymouth Laboratory; and we are much indebted to the Director and Staff of the Laboratory for the generous and efficient way in which they supplied us with Lophius in good condition and with any materials which proved necessary for our investigations.

As soon as the fish were brought in, they were killed by a blow on the head, and one of the branchial arteries was cannulated for bleeding into heparin. Several Lophius of all sizes up to $100 \mathrm{~cm}$. long were bled, and the blood was kept in cold storage. As soon as more than $500 \mathrm{ml}$. of blood had been collected, a perfusion experiment was carried out, using a kidney of a large-sized fish. The blood was put in a glass bulb at variable and measured levels above the kidney. Rubber tubing and a glass cannula inserted into the renal end of the caudal vein carried the blood to the gland, while the effluent was collected in a funnel and returned to the bulb. By so doing, the perfusion was made at room temperature, except in one experiment where all the glassware was kept in ice in order that the kidney should be perfused at a temperature of about $5^{\circ} \mathrm{C}$.

In Exp. 2 the blood was oxygenated and, after perfusing the kidney, reoxygenated in a large-sized spiral tube down which it flowed in a thin layer, while oxygen ran through in the opposite direction. The degree of oxygenation of the blood was not measured. In Exps. I, 3 and 4 unreoxygenated venous blood was used.

Urine was collected from the ureter, and microdeterminations were made of total nitrogen (Kjeldahl), chlorine (St Russnyak, I926, p. 2II), and of magnesium (colorimetrically, as described by Fister, I950).

\section{Results}

\section{EXPERIMENT I}

Blood from several Lophius was collected the day before and heparinized. The perfused kidney (from L. no. I8, weighing $10.8 \mathrm{~kg}$.) weighed I9 g. Perfusion was started $47 \mathrm{~min}$. after the arrival of the fish. Bladder urine before experiment: $5 \mathrm{ml}$. with $4 \mathrm{I} 4 \mathrm{mg}$. $\mathrm{Cl} / \mathrm{IOO} \mathrm{ml}$. The results are given in Table I. Perfusion pressures are in mm. of blood, blood flows in $\mathrm{ml} . / \mathrm{g}$. of fresh kidney per minute, and urine flows in ml. per gram of fresh kidney per hour. Room temperature: $24 \cdot 7^{\circ} \mathrm{C}$.

This is the first renal blood perfusion experiment carried out in Lophius. We do not know the pressure in the caudal vein at its entrance to the kidney in the live animal, but considering the thinness of the wall, this pressure is likely to be very low. The urine flow began with a blood pressure of $20 \mathrm{~mm}$., and raising this pressure progressively from 40 to $50 \mathrm{~mm}$. up to $\mathrm{I} 20 \mathrm{~mm}$. had no influence on the rate of urine flow. This flow is abundant, and especially so when we consider that about $40 \%$ of the kidney is lymphoid and not renal tissue: the rate of flow (per g. fresh tissue) is, indeed of the same order as that in the living dog. The urine is acid ( $\mathrm{pH}$ 5), and colourless. The kidney does not concentrate chloride, but concentrates total non-protein nitrogen more than five times in sample.3, and three times in sample 5. Magnesium is highly 


\section{TABLE I. EXPERIMENT I}

\begin{tabular}{|c|c|c|c|c|c|c|c|c|c|}
\hline \multirow[b]{2}{*}{$\begin{array}{l}\text { Time } \\
\text { (min.) }\end{array}$} & \multirow[b]{2}{*}{$\begin{array}{c}\text { Perfusion } \\
\text { pressure, } \\
\text { (mm. } \\
\text { blood) }\end{array}$} & \multirow[b]{2}{*}{$\begin{array}{l}\text { Blood } \\
\text { flow } \\
\text { (ml./g./ } \\
\text { min.) }\end{array}$} & \multicolumn{6}{|c|}{ Urine } & \\
\hline & & & No. & $\begin{array}{l}\text { Volume } \\
\text { (ml.) }\end{array}$ & ml./g./hr.) & $\begin{array}{c}\mathrm{Cl} \\
\text { (mg./ } \\
\text { I00 ml.) }\end{array}$ & $\begin{array}{c}\mathrm{Mg} \\
\text { (mg./ } \\
\text { IOO ml.) }\end{array}$ & 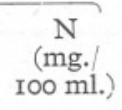 & \\
\hline 0 & 20 & 0.36 & - & - & - & - & - & - & $\begin{array}{l}\text { Perfusion started } \\
\text { (venous blood) }\end{array}$ \\
\hline 20 & - & & & First c & drop collecte & & & & $\mathrm{pH}$ of urine: 5 \\
\hline 4I & I5 & 0.20 & - & - & - & - & - & - & - \\
\hline 42 & 40 & 0.48 & - & - & - & - & - & 一 & Pressure raised \\
\hline 60 & 40 & 0.52 & I & $2 \cdot 0$ & 0.16 & 594 & - & 一 & $\mathrm{pH}$ of urine: 5 \\
\hline 73 & 50 & 0.65 & - & - & - & - & - & 一 & - \\
\hline 90 & 50 & 0.55 & 2 & $2 \cdot 0$ & 0.20 & 598 & - & - & - \\
\hline 93 & $50 \rightarrow 65$ & $0.55 ; \mathrm{I} \cdot \mathrm{IO}$ & - & - & - & - & - & 一 & - \\
\hline 98 & 70 & - & 一 & - & - & - & - & - & - \\
\hline II 8 & 70 & - & 3 & $2: 2$ & 0.25 & 596 & 270 & II3 & - \\
\hline I50 & $70 \rightarrow \mathrm{I} 20$ & $\mathrm{I} \cdot \mathrm{IO} \rightarrow$ & 4 & $2 \cdot 0$ & 0.20 & 584 & 255 & - & Pressure raised \\
\hline I53 & I2O & $4 \cdot 60$ & 一 & - & - & - & - & - & - \\
\hline 180 & $\mathrm{I} 20$ & - & 5 & $2 \cdot 0$ & 0.20 & - & 222 & 70 & - \\
\hline 188 & - & - & 6 & $I \cdot 2^{\star}$ & - & - & I80 & - & $\begin{array}{c}\mathrm{Cl} \text { in plasma } 576 \\
\mathrm{~N} 23 \mathrm{mg} . / 100 \mathrm{ml}\end{array}$ \\
\hline
\end{tabular}

TABLE II. EXPERIMENT 2

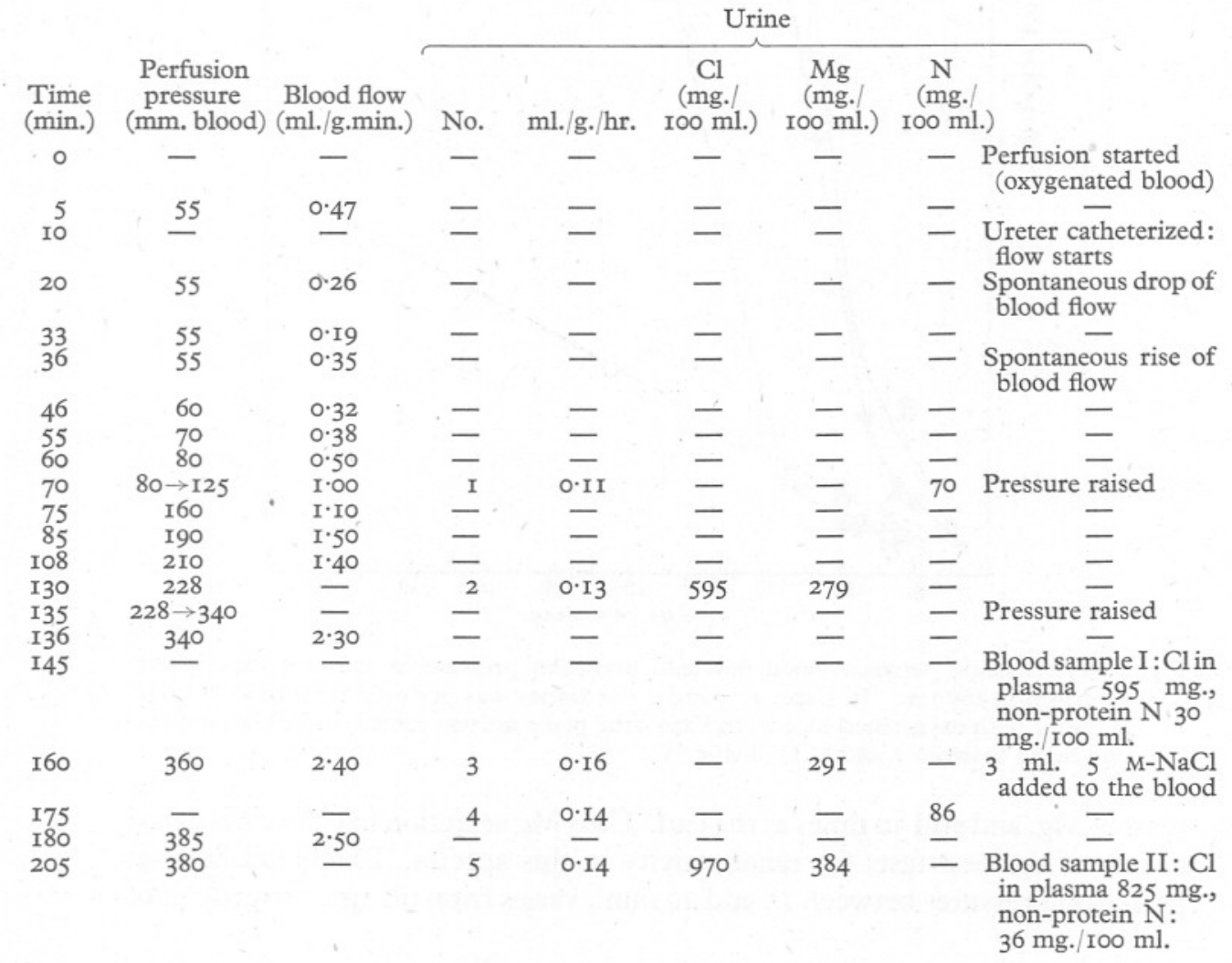


concentrated seeing that Lophius plasma contains only about $6 \mathrm{mg}$./100 ml.: at the beginning of the experiment the urine $\mathrm{Mg}$ was about 45 times the

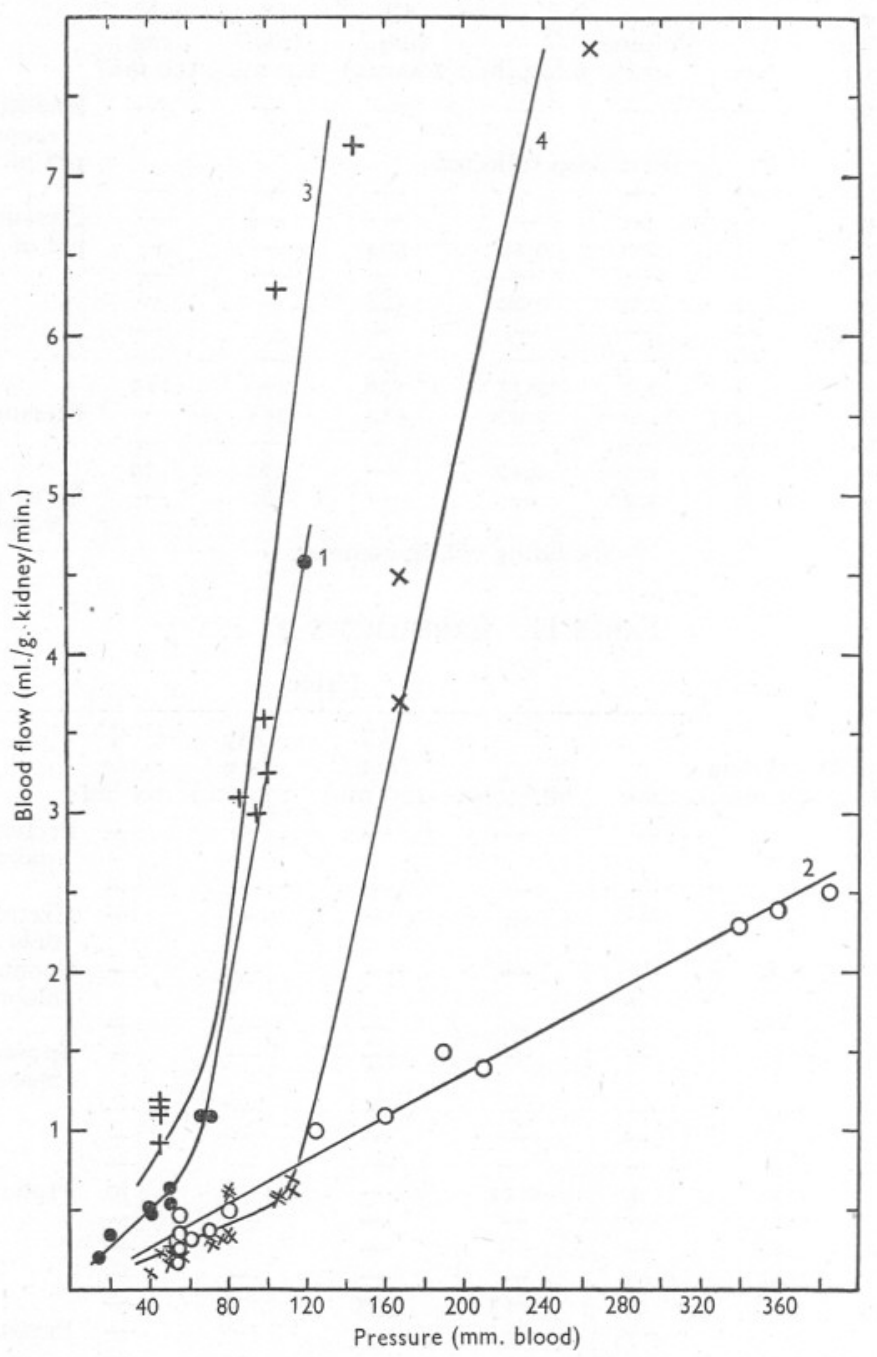

Fig. I. The relation between blood flow and perfusion pressure in the four experiments described in the text. In Exps. I, 3 and 4 the kidney was perfused with venous blood, in Exp. 2 with oxygenated blood. In Exp. 4 the perfusate was cooled, its inflow temperature being between 2 and $8^{\circ} \mathrm{C}$ (Table IV).

plasma $\mathrm{Mg}$, and still 30 times at the end. Thus $\mathrm{Mg}$ secretion may be considered as one of the best tests for renal activity in this species. The blood flow, at perfusion pressures between 15 and $40 \mathrm{~mm}$., varies from 0.2 up to $0.5 \mathrm{ml} . / \mathrm{g}$. of 
fresh kidney per minute, and when the pressure is raised from 40 to $70 \mathrm{~mm}$. the flow increases from 0.5 to $\mathrm{I} \cdot \mathrm{I} \mathrm{ml}$./min. With a higher pressure $(\mathrm{I} 20 \mathrm{~mm}$.), the response is proportionally much greater, showing that the resistance of the vascular bed has diminished (Fig. I).

\section{EXPERIMENT 2}

Blood was collected from several Lophius just before the perfusion, and the day before. The blood was oxygenated. Room temperature $24 \cdot 2^{\circ} \mathrm{C}$. The perfused kidney (from L. no. 28 weighing $7 \mathrm{~kg}$.) weighed $17 \mathrm{~g}$. The results of this experiment are given in Table II.

The renal blood flow shows spontaneous fluctuations, but follows the pressure more or less passively throughout (Fig. I). The urine flow increases with perfusion pressure, but only to a very small extent: a 500\% increase in pressure is associated with a $25 \%$ increase in urine flow. The kidney excretes $\mathrm{Cl}$ at the same concentration as it is present in the plasma until the plasma level is raised from 595 to $825 \mathrm{mg}$./ $100 \mathrm{ml}$.; from then on a slight concentration of $\mathrm{Cl}$ ( $970 \mathrm{mg}$./ $/ 00 \mathrm{ml}$.) occurs. Nitrogen is concentrated twice, and this concentration continues throughout the experiment. Magnesium is highly concentrated, as in Exp. I.

\section{EXPERIMENT 3}

$270 \mathrm{ml}$. mixed heparinized venous non-oxygenated blood was used as the perfusate. Room temperature $21 \cdot 7^{\circ} \mathrm{C}$. The perfused kidney (from L. no. 36 weighing $7 \mathrm{~kg}$.) weighed I2 g. Bladder urine before experiment: $20 \mathrm{ml}$. with $\mathrm{Cl} .680 \mathrm{mg}$. and nonprotein nitrogen $75 \mathrm{mg}$./ $/ 100 \mathrm{ml}$. The results of this experiment are given in Table III.

The renal blood flow follows the perfusion pressure, but the variations of flow are proportionally very much greater than the variations of pressure (Fig. I). In this experiment the urine flow is directly proportional to the perfusion pressure. Chloride in the urine is slightly concentrated from the beginning, and more so after the plasma chloride is raised. Non-protein nitrogen is high in the plasma and is not concentrated. Magnesium is again highly concentrated.

\section{EXPERIMENT 4}

$550 \mathrm{ml}$. venous non-oxygenated mixed heparinized blood was used as the perfusate. The blood reservoirs were cooled in ice with sodium chloride. The kidney weighed $23 \mathrm{~g}$. (from L. no. 45 weighing Io $\mathrm{kg}$. fished the previous day and kept alive in the aquarium). The results of this experiment are given in Table IV.

The blood flow is roughly proportional to the perfusion pressure up to a pressure of about $100 \mathrm{~mm}$.; thereafter the variations of flow are proportionally very much greater than those of pressure (Fig. I). After the kidney had been subjected to a pressure of $285 \mathrm{~mm}$. of blood, the return of blood flow to its initial value when the pressure was lowered to its initial value (column I, 290-300 min.) shows that the vessels had not lost their elasticity as a result of this operation. The urine flow, non-existent at the beginning, begins to be 
appreciable only at a pressure of $70 \mathrm{~mm}$., and at higher pressures there is no parallelism between perfusion pressure and urine flow. Nitrogen is concentrated three times at the most, no more than during perfusion at room temperature. Chloride is not concentrated. Magnesium is highly concentrated, but no more, or even less, than at room temperature.

\section{TABle III. EXPERIMENT 3}

\begin{tabular}{|c|c|c|c|c|c|c|c|c|}
\hline \multirow[b]{2}{*}{$\begin{array}{l}\text { Time } \\
\text { (min.) }\end{array}$} & \multirow[b]{2}{*}{$\begin{array}{c}\text { Perfusion } \\
\text { pressure } \\
\text { (mm. blood) }\end{array}$} & \multirow[b]{2}{*}{$\begin{array}{l}\text { Blood flow } \\
\text { (ml./g./min.) }\end{array}$} & \multicolumn{5}{|c|}{ Urine } & \\
\hline & & & No. & $\mathrm{ml} . / \mathrm{g} . / \mathrm{hr}$. & $\begin{array}{c}\mathrm{Cl} \\
\text { (mg./ } \\
\text { roo ml.) }\end{array}$ & $\begin{array}{c}\mathrm{Mg} \\
\text { (mg./ } \\
\text { roo ml.) }\end{array}$ & $\begin{array}{l}\mathrm{N} \\
\text { (mg. } \\
\text { IOO ml.) }\end{array}$ & \\
\hline$\circ$ & - & - & - & - & - & - & - & $\begin{array}{l}\text { Perfusion started } \\
\text { (venous blood) }\end{array}$ \\
\hline Io & 50 & 0.7 & - & - & - & - & - & $\begin{array}{l}0.2 \mathrm{ml} \text {. urine in } \\
\text { cannula }\end{array}$ \\
\hline I5 & 45 & $I \cdot 15$ & - & - & - & - & - & $\begin{array}{l}\text { Spontaneous rise of } \\
\text { blood flow }\end{array}$ \\
\hline $\begin{array}{l}30 \\
50\end{array}$ & 45 & 0.92 & - & - & - & 二 & - & - \\
\hline $\begin{array}{l}50 \\
62\end{array}$ & $\begin{array}{l}45 \\
45\end{array}$ & $\begin{array}{l}\mathrm{I} \cdot 10 \\
\mathrm{I} \cdot 20\end{array}$ & 二 & 二 & $\bar{z}$ & 二 & $\bar{z}$ & 二 \\
\hline 70 & $45 \rightarrow 85$ & - & $\mathrm{I}$ & 0.10 & - & - & - & Pressure raised \\
\hline 73 & 87 & 3. I0 & - & - & - & - & - & - \\
\hline $\begin{array}{l}108 \\
\text { II } 5\end{array}$ & $\underset{I O I \rightarrow I 40}{\operatorname{IOI}}$ & 3.30 & $\overline{2}$ & $\overline{0.20}$ & 二 & $\overline{345}$ & $\overline{64}$ & Pressure raised \\
\hline 120 & I 45 & $7 \cdot 20$ & - & - & - & - & - & - \\
\hline 125 & - & - & - & - & - & - & - & $\begin{array}{l}\text { Blood sample I: } \\
\text { Plasma Cl 670 mg. } \\
\text { non-protein N } \\
87 \mathrm{mg} . / \mathrm{IOO} \mathrm{ml} \text {. }\end{array}$ \\
\hline I40 & $\mathrm{I} 45 \rightarrow \mathrm{IO} 5$ & - & 3 & 0.29 & 760 & $32 I$ & - & $\begin{array}{l}2 \mathrm{ml} \text {. I } \mathrm{M}-\mathrm{NaCl} \\
\text { added to the blood. } \\
\text { Pressure lowered }\end{array}$ \\
\hline I46 & 105 & $6 \cdot 30$ & - & - & - & - & - & - \\
\hline 152 & - & - & - & - & - & - & - & $\begin{array}{l}\text { Blood sample II } \\
\text { Plasma Cl } 787 \text { mg. } \\
\text { I00 ml. }\end{array}$ \\
\hline 165 & - & - & 4 & 0.16 & - & 348 & - & - \\
\hline 167 & 100 & $3 \cdot 60$ & - & - & - & & - & - \\
\hline 200 & 100 & - & 5 & 0.18 & 894 & 378 & - & - \\
\hline 210 & 95 & 3.00 & $\overline{6}$ & - & - & - & - & - \\
\hline 220 & 95 & - & 6 & o. & - & - & - & - \\
\hline 235 & - & - & 7 & 0.16 & - & - & 80 & - \\
\hline
\end{tabular}

\section{Discussion}

Lophius kidneys, perfused with heparinized blood, retain for several hours the power of producing urine. This urine is colourless but its chemical composition shows that the gland is actively secreting.

Among the constituents investigated, magnesium was concentrated up to 50 times by the kidney and reached the same degree of concentration as is found in the bladder urine of freshly killed fish. Total non-protein nitrogen is also concentrated by the perfused kidneys, but not so much as in the living fish. Some of the separate constituents are perhaps more concentrated than the figures for the total non-protein nitrogen would suggest: the small volume of the urine samples did not enable us to answer this question. The perfused 
TAble IV. Experiment 4

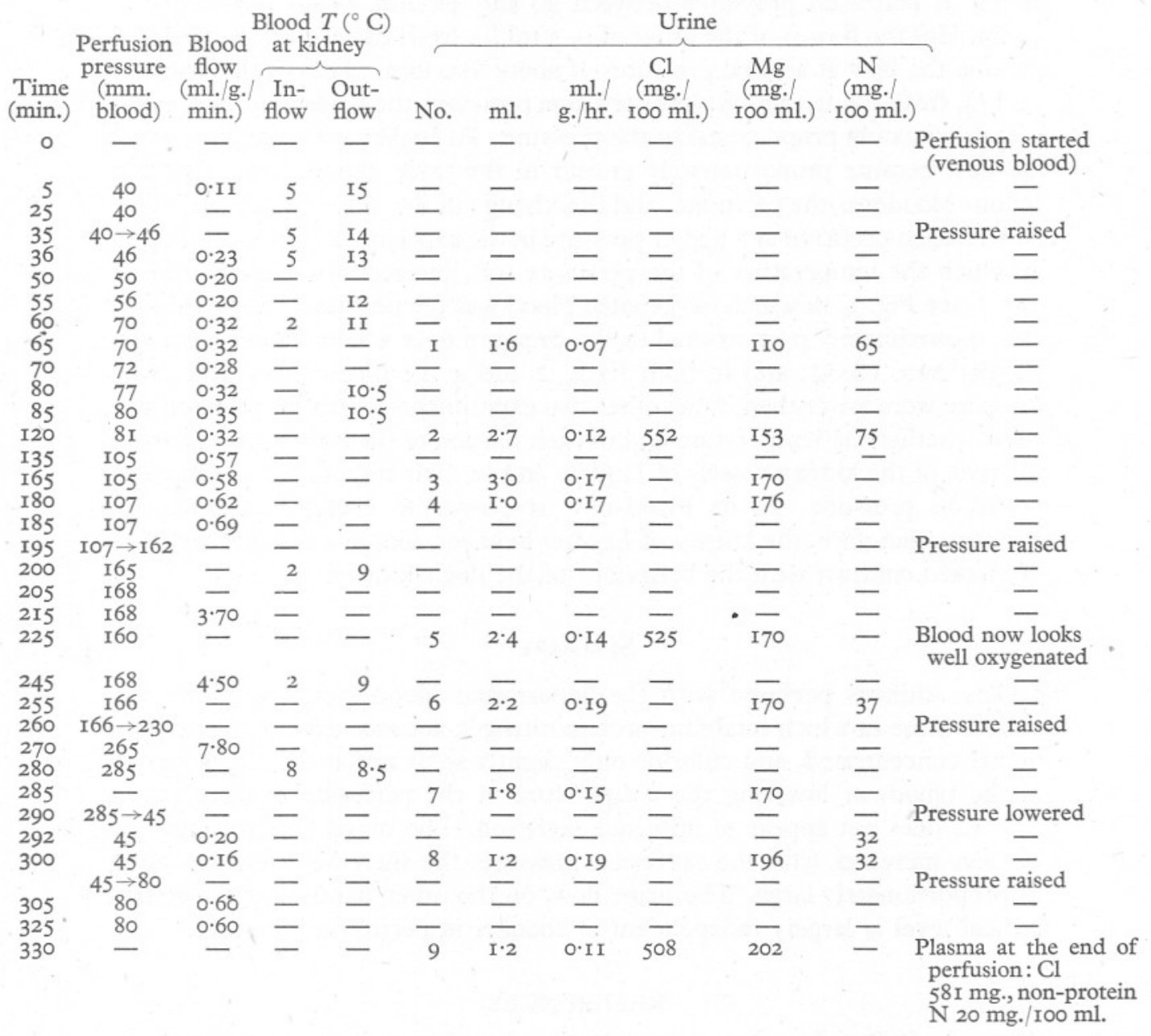

kidney excretes chloride usually at the same concentration as in plasma; but when the plasma chloride is artificially raised the concentration of chloride in the urine is higher than that in the plasma.

The activity of the kidney does not seem to be improved by oxygenation of the blood, which is not surprising seeing that venous blood is by far the main supply to such kidneys under normal conditions. Neither is this activity appreciably different at room temperature and at low temperatures close to those at which Lophius normally lives. Changes in perfusion pressure up to $100-150 \mathrm{~mm}$. of water raised the urine flow; above $150 \mathrm{~mm}$. there was no effect. This result is in marked contrast with the effects of such changes in a glomerular kidney. 
The renal venous vascular net offers but little resistance to the flow of blood: at perfusion pressures between 20 and $40 \mathrm{~mm}$. blood (about $\mathrm{I} \cdot 5$ to $3 \mathrm{~mm} . \mathrm{Hg}$ ) the flow is of the order of $0,3 \mathrm{ml} . / \mathrm{g}$. fresh tissue/min., whereas in the dog the flow at arterial pressures of about $100 \mathrm{~mm}$. $\mathrm{Hg}$ is of the order of $3 \mathrm{ml}$./g. fresh tissue/min. At low perfusion pressures the blood flow in Lophius is approximately proportional to the pressure. At higher pressures, however, the flow became proportionately greater in the three experiments in which venous blood was the perfusate, and this change in the slope of the pressureflow relation occurred at a higher pressure in the experiment (no. 4, see Fig. I) in which the temperature of the perfusate was lowered. In the experiment (no. 2, see Fig. I) in which oxygenated blood was the perfusate the blood flow was approximately proportional to the pressure over a very wide range, viz. 50-385 mm. blood; and in both Exps. 2 and 4 the blood flows at a given pressure were lower than in the other two experiments. Further research will show whether the temperature and oxygen tension of the blood play a part in the tone of the kidney vessels of Lophius and in their responses to changes in perfusion pressure. In its blood-flow responses to changes in perfusion pressure, therefore, the kidney of Lophius behaves, too, in a manner which is in marked contrast with the behaviour of the dog's kidney.

\section{SUMMARY}

Lophius kidneys perfused with the heparinized blood (venous) of the fish secrete urine in which total non-protein nitrogen is concentrated, magnesium highly concentrated, and chloride only slightly so or not at all. Oxygenation of the blood, or lowering the temperature of the perfusate from $c .20^{\circ}$ to c. $5^{\circ} \mathrm{C}$. does not appear to influence secretion. The blood flow through the kidneys increases with the perfusion pressure, the increase often becoming disproportionately large. The urine flow, on the other hand, above a certain critical level is largely independent of changes in perfusion pressure.

\section{REFERENCES}

BrULL, L. \& DoR, M., I940. Consommation d'oxygène et production d'acide carbonique du rein de chien normal transplanté. Arch. Int. Physiol., T. 50, pp. 244-56.

Brull, L. \& Louis-BAR, D., I950. The secretion of urine at high systemic pressures as studied by means of the mechanical heart with coagulable blood. Arch. Int. Physiol., T. 58, pp. 329-42.

1953. Venous flow and urine secretion of innervated kidneys perfused at different pressure levels with coagulable blood. Arch. Int. Physiol., T. 6I, pp. I-4.

BrULL, L. \& Nizet, E., I953. Blood and urine constituents of Lophius piscatorius L. fourn. Mar. Biol. Assoc., Vol. 32, pp. 32 I-8.

FISTER, H. J., 1950. Procedures for Spectrographic Chemistry. New York.

St RussnyaK, I926. In Chimie Biologique médicale. By Derrien, E. \& Fontes, G. 440 pp. Paris. 